\title{
Influence of LKPD to Facilitate Cooperative Group Investigation in Improving Students' Science Process Skills
}

\author{
*Suliwa ${ }^{1}$, W Widodo ${ }^{2}$, Munasir ${ }^{3}$ \\ 1Postgraduate of Science Education, Universitas Negeri Surabaya, Indonesia \\ 2Department of Physics Education, Faculty of Mathematics and Natural Science, Universitas Negeri Surabaya, \\ Indonesia \\ ${ }^{3}$ Department of Physics, Faculty of Mathematics and Natural Science, Universitas Negeri Surabaya, Indonesia
}

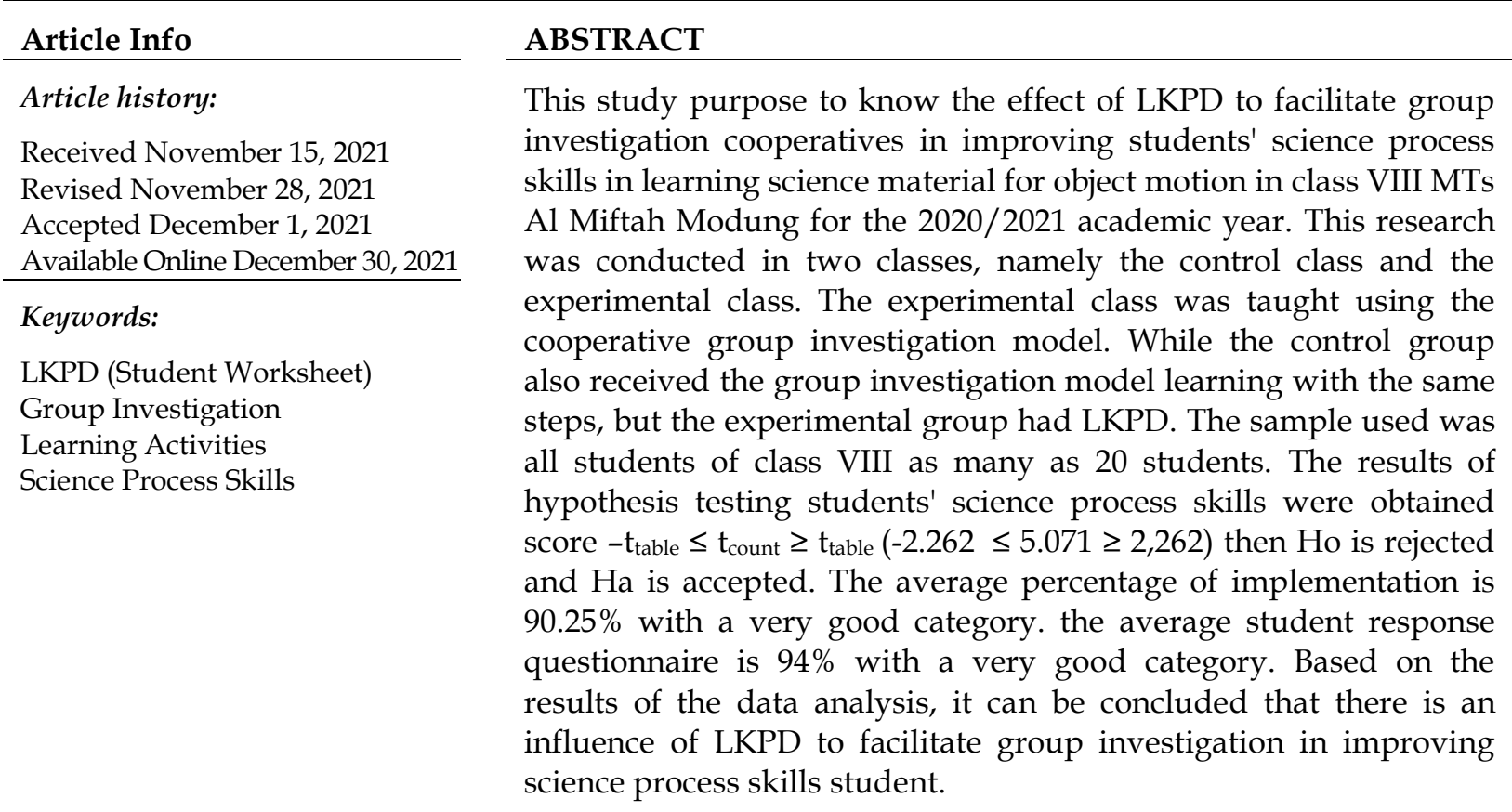

\section{INTRODUCTION}

Education is an important place which provides all the knowledge, scientific attitudes and various kinds of skills that students need in fulfilling their daily needs. The US-based association stated that the skills needed in the modern 21st century are "four skills", communication, collaboration, critical thinking, and creative (Zubaidah, 2016). These skills are very important to be trained on students in every subject, especially the science in motion of objects. One of the skills that the researchers examined in this research is science process skills as one of the skills that students must possess because the indicators contain skills in facing the era of 21st century progress.

Science learning is essentially developing amount of skills that are in accordance with the changes in the current era towards the future era (Suastra, 2009). The skills in meant are scientific process skills, scientific products (concepts, understanding, facts, ideas), and scientific attitude. The implementation of the nature at science learning in learning is the responsibility of the teacher as a transmitter, regulator, facilitator in learning, and students as learning actors (student-centered learning).

Carin and Sund (1989) stated that science has three major elements: attitude, process methods and products. This formula is a benchmark that science/science learning is emphasized not only on the product, but also on attitudes and processes. Process abilities that 
are expected to be possessed by students in this case are science process skills. Science process skills are the benchmark for the implementation of the K13 curriculum adopted by education in Indonesia.

The fact during the learning process in the field the teacher acts as a source of knowledge information but students only act as recipients of knowledge information. Teachers should act more as facilitators and motivators in the implementation of learning activities so that learning objectives can be achieved as expected. The impact on the knowledge gained is only limited to mere memorization, not on the basis of aspects of the student's process. In fact, to get the discovery of concepts, experiences, facts or principles required a process skill. The process skills in meant are science process skills.

However, in the actualization of learning in schools, the opposite facts were found. Based on observations at MTS al Miftah Bangkalan, especially in learning science class VIII on object motion material it is felt very boring because the process of presenting learning carried out by the teacher, among them 1) monotonous / not dynamic, 2) textbooks are the main source, 3) lecture learning method, and discussion is more dominant in learning, 4) learning has not taught and trained science process skills but more on the basic skills of memorizing and taking notes, 5) learning has not trained and developed skills that can foster student curiosity or scientific attitude.

Viyayanti and Dwikoranto (2021) said that cooperative learning was chosen because it was considered suitable and appropriate to achieve the learning objectives, for improving students' science process skills. Students can work together on groups in finding, compiling, processing, and communicating related problems at material motion of objects directly. Cooperative learning model is a learning model that requires the active involvement of students to work together in heterogeneous groups with learning success determined by working together with groups, the purpose of forming groups in cooperative learning models is to provide opportunities for all students to be actively involved. active in the process of thinking and learning activities. Slavin (2010) suggests that group investigation cooperative learning has a great opportunity to improve cooperative relationships between students and other students in achieving common goals through small group discussions. This is an important reason that researchers are interested in applying the group investigation model at MTs AL Miftah schools to improve students' science process skills.

Sanjaya (2008) said that the factors influence the learning process system include students, teachers, facilities and infrastructure, as well as environmental factors are also involved. Technological advances that are growing rapidly, especially in the industrial era 4.0 provide solutions to make learning seem interesting, namely by utilizing technology in the manufacture of learning media that helps in the process of delivering material to students. In this study, researchers used student worksheets (LKPD) to facilitate cooperative group investigation models so that students were directed and systematically measured so that science process skills could be seen in students.

Science process skills are classified into two, namely basic and integrated science process skills. Basic science process skills include observing, inferring, measuring, classifying, predicting/predicting, and communicating (Gasila et al., 2019). Meanwhile, integrated science process skills include identifying problems, controlling variables, formulating hypotheses, reading graphs, interpreting data, defining operations, and conducting experiments (Sayekti, 2017). In this study, the indicators of science process skills used were formulating problems, formulating hypotheses, formulating variables, planning experiments, conducting experiments, presenting tables, concluding, and communicating

\section{RESEARCH METHOD}

\section{Research Design}

This research is included in the Pretest-Posttest control Group Design, namely the experimental group and the control group (Hardani, 2020). In this research design, observation was applied 
during the pretest, the learning process used teaching materials in the form of LKPD, and posttest. The comparison obtained from the results of the pretest and posttest between the control and experimental groups will be analyzed and assumed to have an effect after being given treatment in the form of Group Investigation cooperative learning with student learning aids in the form of LKPD. During the learning process, science process skills will be assessed either as a group or each student. The design can be described as follows.

Tabel 1. Design Research

\begin{tabular}{lll}
\hline $\mathrm{O}_{1}$ & $\mathrm{O}_{2}$ \\
\hline $\mathrm{O}_{3}$ & $\mathrm{X}$ & $\mathrm{O}_{4}$ \\
\hline
\end{tabular}

Description:

$\mathrm{O}_{1}$ : Pretest, serves to find out how students' knowledge of the material to be taught before being given treatment in the control group

$\mathrm{O}_{2}$ : posttest control group.

$\mathrm{X}$ : treatment, namely learning using the Group Investigation cooperative model with learning aids in the form of LKPD on object motion material.

$\mathrm{O}_{3}$ : Pretest experimental group.

$\mathrm{O}_{4}$ : posttest experimental group.

\section{Research Procedure}

This research was conducted in two classes, namely the control class and the experimental class. The experimental class was taught using the cooperative group investigation model. While the control group also received the group investigation model learning with the same steps, but the experimental group had LKPD.

\section{Subject, Place and Time of research}

The subjects of this study were all students of class VIII MTs Al Miftah for the academic year 2020/2021 with a total of twenty students. 10 students were randomly selected as research subjects who received treatment.

\section{Achievement Indicators}

The indicators of science process skills studied include formulating problems, formulating hypotheses, formulating variables, planning experiments, conducting experiments, presenting tables, concluding, and communicating. Formulating problems with student achievement being able to find and formulating problems in the form of questions about an event, information or data. Formulating variables with student achievement being able to find and understand the variables involved in the problem. Planning experiments with the achievement of the ability to compose work steps in writing, determine experimental variables, create and apply work steps and how to process data. Conduct experiments with the achievement of students being able to use tools and materials in experiments, able to control the variables involved, and able to take measurements according to work steps. Presenting tables with student achievements in processing experimental data, organizing data in tabular form that makes it easier to inform data and makes it easier to draw conclusions. Concluding with the achievement of students are able to provide a final decision which is the essence of the problem based on data or information. Communicating with the achievement of students are able to convey the results of experimental data directly in front of the class in the form of suggestions, responses, criticisms, and information or conclusions from the experiment. The achievement of each indicator is declared complete if it gets a score above 65. 


\section{DATA ANALYSIS}

\section{Validation of Learning Tools}

Instruments of learning tools include lesson plans, LKPD, and questionnaires. As for the implementation of the learning instrument, before being used, the validity test was carried out first. The results of the validation were analyzed using the combined mean percentage formula to determine the validity of the learning tools.

$$
V=\frac{\text { score obtained }}{\text { max score }} \times 100 \%
$$

The assessment category for the validation results is shown in the table below:

Table 1. Category of learning tool validity

\begin{tabular}{ll}
\hline \multicolumn{1}{c}{ Score } & \multicolumn{1}{c}{ Category } \\
\hline $0 \%-24 \%$ & Invalid and not worth using \\
$25 \%-49 \%$ & Worth using with many revisions \\
$50 \%-74 \%$ & Worth using with a little revision \\
$75 \%-100 \%$ & Valid and suitable for use without revision \\
\hline
\end{tabular}

\section{Test Instrument Validation}

Before the test was used to measure students' understanding, the validity and reliability of an instrument were first measured from the assessment of the validator team. The analytical steps carried out for the test items include validity and reliability. The test consists of two kinds, namely pretest and posttest with the same questions.

The measurement of validity uses the Aiken item validity index which is formulated as follows:

$$
\mathrm{V}=\frac{\sum S}{\mathrm{n}(\mathrm{c}-1)}
$$

(Aiken, 1980)

Description:

$$
\begin{array}{ll}
\mathrm{V} & \text { : Value index validity } \\
\mathrm{S} & \mathrm{:} \mathrm{r}-\mathrm{I} 0 \\
\mathrm{n} & \text { : Number of validators } \\
\mathrm{I} 0 & \text { : Lowest validity value } \\
\mathrm{C} & \text { : Highest validity value } \\
\mathrm{r} & \text { : Value given by validator }
\end{array}
$$

The results of the value index validity are in the range of values $0-1$. Items with a validity index $\leq 0.4$ are categorized as invalid, but if the validity index $\geq 0.8$ is categorized as very valid. The category of the results of the validity index is stated as follows:

Table 2.Validity Correlation Coefficient

\begin{tabular}{cc}
\hline Percentage & Category \\
\hline $0.8<$ V 1.0 & Very high \\
$0.6<\mathrm{V} 0.8$ & High \\
$0.4<\mathrm{V} 0.6$ & Enough \\
$0.2<\mathrm{V} 0.4$ & Low \\
$0 \mathrm{~V} 0.2$ & Very low \\
\hline
\end{tabular}

(Arikunto, 2015)

\section{Reliability}

Reliability is carried out to test the stability of the instrument used. Instrument reliability testing (Utami et al., 2019) uses the Borich reliability formula:

$$
R=\left[1-\frac{A-B}{A+B}\right] \times 100 \%
$$


Description:

A : Frequency of the highest value of the validator

B : Frequency of the lowest value of the validator

The results of the assessment data from the validator will be tested using formula 3.2 to determine the reliability of the test instrument. The test is said to have good reliability if the value obtained is $\geq 75 \%$.

\section{Item Sensitivity}

Sensitivity analysis was carried out to determine how much the ability of each test item was to distinguish between students with high abilities and students with low abilities. The sensitivity index of essay questions is calculated using the following calculation formula:

$$
S=\frac{\sum_{1}^{n} B_{\text {post }}-\sum_{1}^{n} B_{\text {pre }}}{N\left(\text { score }_{\max }-\text { score }_{\min }\right)}
$$

Description:

(Gronlund, 2016)

\section{$\mathrm{S}$}

$\mathrm{N}$

Score $_{\max } \quad$ : The maximum score obtained by students

Score ${ }_{\min } \quad$ : The minimum score obtained by students

$\sum_{1}^{n} B_{\text {post }} \quad$ : Total score of students after learning

$\sum_{1}^{n} B_{\text {pre }} \quad$ : Total score of students before learning

The items are said to be good and sensitive to learning if the sensitivity value is $\geq 0.30$.

\section{Difference Power}

Purwanto (2010) said that difference power is the ability of items to distinguish students with high understanding (upper group) and students with low understanding (lower group). The difference power of essay questions is calculated using the following formula:

$$
D B=\frac{\bar{x}_{A-} \bar{x}_{B}}{x_{\max }}
$$

(Arikunto, 2015)

Description:

DB : The value of discriminating power of essay questions

$\bar{x}_{A}$ : The average value of the students in the upper group

$\bar{x}_{B}:$ The average value of the lower group students

$X_{\max }$ : The maximum value of the question

The results of differentiating power values and assessment categories are stated in the table below:

Table 3. Difference Power Category

\begin{tabular}{cc}
\hline Score & Category \\
\hline $0.71-1.00$ & Very good \\
$0.41-0.70$ & Well \\
$0.21-0.40$ & Medium \\
$0.00-0.20$ & Bad \\
\hline
\end{tabular}

(Arikunto, 2015) 


\section{Question Difficulty Level}

Arifin (2013) argues that "the calculation of the level of difficulty of a question is a measurement of how big the degree of difficulty of a question is". The difficulty level of the essay questions is calculated using the formula.

Description:

$$
\mathrm{TK}=\frac{\bar{x}}{x_{\max }}
$$

TK : Difficulty level

$\bar{x} \quad$ : The average score obtained by students for each item

$\mathrm{X}_{\max }$ : Question maximum score

With the category of the difficulty level of the question.

Table 4. Difficulty Category

\begin{tabular}{cc}
\hline Score & Category \\
\hline $0.71-1.00$ & Easy \\
$0.31-0.70$ & Medium \\
$0.00-0.30$ & Difficult \\
\hline
\end{tabular}

(Arifin, 2013)

\section{Learning Implementation}

Learning completeness data from observers was analyzed to measure the practicality of the lesson plans in terms of the level of implementation of the planning stages during the learning process, calculated using the following formula:

$$
\text { Learning Implementation }=\frac{\Sigma x}{n} \times 100 \%
$$

(Arikunto, 2015)

Description:

$\mathrm{P} \quad$ : Percentage Value of Learning Implementation

$\mathrm{x}$ : Total Value

$\mathrm{N}$ : Number of Questions

The results of the analysis are then converted into the following implementation categories:

Table 5. Category of Learning Implementation Value

\begin{tabular}{cc}
\hline Percentage & Category \\
\hline $86 \%-100 \%$ & Very good \\
$71 \%-85 \%$ & Well \\
$51 \%-70 \%$ & Not enough good \\
Value $50 \%$ & Not good \\
\hline
\end{tabular}

(Arikunto, 2015)

\section{Student Response Questionnaire}

Questionnaires were given to students after receiving treatment, namely the application of LKPD in facilitating cooperative Group Investigation. Questionnaire containing 10 questions containing indicators of model suitability, model help, model attractiveness, and model convenience with Likert scale categories, namely, STS (strongly disagree), TS (disagree), S (agree), SS (strongly agree). The results of the questionnaire were then analyzed to determine student responses to the LKPD cooperative model of Group investigation with the mean formula (the average score obtained):

$$
\text { score }=\frac{\text { score obtained }}{\max \text { score }} \times 100 \%
$$


Table 6. Category of Student Response Questionnaire Assessment

\begin{tabular}{cc}
\hline Percentage & Category \\
\hline $0 \%-25 \%$ & Not very good \\
$26 \%-50 \%$ & Not good \\
$51 \%-75 \%$ & Well \\
$76 \%-100 \%$ & Very good \\
\hline
\end{tabular}

\section{Observation of Students' Science Process Skills}

Observation data on indicators of science process skills in experiments I and II were analyzed using the formula:

$$
\text { Score KPS }=\frac{\text { score obtained }}{\max \text { score }} \times 100
$$

With the category of achievement of science process skills

\begin{tabular}{cc} 
Table 7. Science Process Skill Achievement Category \\
\hline KPS achievement value & Category \\
\hline $0-20$ & Not very good \\
$21-40$ & Not good \\
$41-60$ & Enough \\
$61-80$ & Well \\
$81-100$ & Very good \\
\hline
\end{tabular}

\section{Hypothesis Testing}

Testing the hypothesis to answer the hypothesis above by calculating the posttest value data for the experimental group with the control group posttest using the free sample t-test (t-test) formula, if the data is parametric at a significance level of 5\% (0.05) (Sugiyono, 2015), namely:

Information:

$$
t_{\text {hitung }}=\frac{\overline{X_{1}}-\overline{X_{2}}}{\sqrt{\frac{s_{1}{ }^{2} \cdot n_{2}+s_{2}{ }^{2} \cdot n_{1}}{n_{1} n_{2}}}}
$$

$\mathrm{t} \quad$ : T value count

$\overline{X_{1}}:$ Average data group 1

$\overline{X_{2}}$ : The mean of group data 2

s1 : The value of the standard deviation of group data 1

s1 : Standard deviation value of group data 2

$\mathrm{n} \quad$ : Number of samples

The basis for making hypothetical decisions are:

If -ttable $<$ tcount $<\mathrm{t}$-table, it can be concluded that $\mathrm{H}_{0}$ is accepted and $\mathrm{H}_{\mathrm{a}}$ is rejected.

If -ttable $\leq$ tcount $\geq t$-table, it can be concluded that $\mathrm{H}_{0}$ is rejected and $\mathrm{H}_{\mathrm{a}}$ is accepted.

\section{RESULTS AND DISCUSSION}

\section{Observation of the Science Process Skills of the experimental group in Group}

John Dewey's view on Group Investigation model is "a group learning model that can encourage student activity and involvement in research" (Slavin, 2010). This view is in line with the thoughts Sharan (1980) which states that the group investigation model is formed into small groups with group members of 2-6 people, each group chooses a topic and makes a report which is then presented with students communicating with each other and exchanging ideas. The science process skills of students in each group for experiments I and II of the experimental class can be seen in Figure 1. 


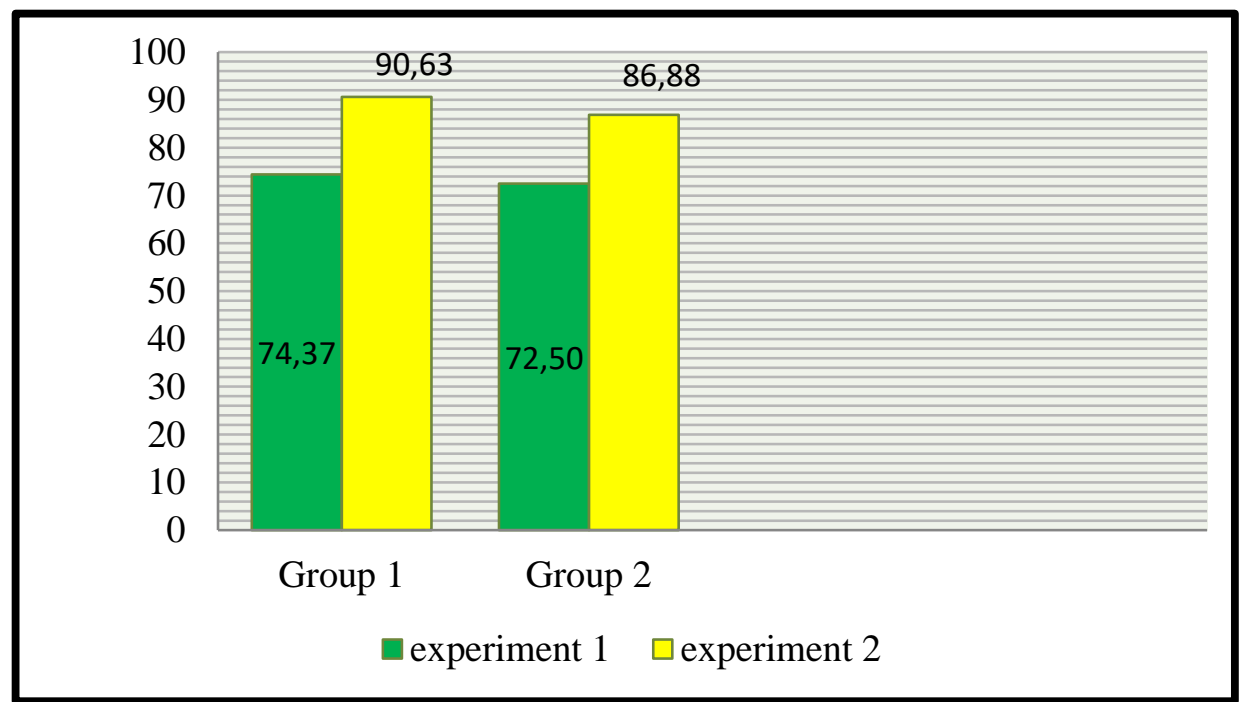

Figure 1. Graphics of PPP Experiments I and II Experimental Groups

Figure 1 above shows that in the first experiment, the group that got the lowest score was group II with a score of 72.50 and the group that got the highest score was group I with a value of 74.37. In experiment II, the group that got the lowest score was group II with a score of 86.88 and the group with the highest score was group I with a score of 90.63. the data showed that the science process skills of all groups in the experimental group increased in experiment II compared to experiment I. This was because on average all groups in experiment II had better understanding of some aspects of science process skills from the previous experiment. Because the members of the experimental group II had received discussion from the teacher in the first experiment, where the material is not much different from the experiment II in which they did, so that students more easily understand the experiments carried out in experiment II.

\section{Experimental Group Science Process Skills in terms of Indicators}

Science process skills in terms of indicators were obtained by calculating the average score for each indicator of science process skills in both experiment I and experiment II. The average science process skills of students in each indicator on experimental I and II can be seen in table 8 .

Table 8. The Value of the Experimental Group KPS Indicators in Experiments I and II.

\begin{tabular}{|c|c|c|c|c|c|c|}
\hline \multirow[b]{2}{*}{ Aspect } & \multicolumn{6}{|c|}{$\begin{array}{l}\text { Science process skills score } \\
\end{array}$} \\
\hline & Group 1 & Category & Group 2 & Category & Average & category \\
\hline $\begin{array}{l}\text { Formulate the } \\
\text { problem }\end{array}$ & 95 & Enough & 95 & Very good & 95 & Very good \\
\hline Formulating a & & & & & & \\
\hline hypothesis & 90 & Very good & 97.5 & Very good & 93.75 & Very good \\
\hline $\begin{array}{l}\text { Formulating } \\
\text { variables }\end{array}$ & 50 & Enough & 75 & Good & 62.5 & Good \\
\hline $\begin{array}{l}\text { Planning an } \\
\text { experiment }\end{array}$ & 85 & Very good & 92.5 & Very good & 88.75 & Very good \\
\hline Doing an experiment & 75 & Good & 85 & Very good & 80 & Good \\
\hline Serving table & 50 & Enough & 85 & Very good & 67.5 & Good \\
\hline Conclude & 77.5 & Good & 95 & Very good & 86.25 & Very good \\
\hline Communicating & 65 & Good & 85 & Very good & 75 & Good \\
\hline Average score & & & & & 81.09 & Very good \\
\hline
\end{tabular}

Table 8 above shows that the average of each indicator of students' science process skills is in the very good category and has increased in practicum II, but in the first experiment there are 
several skill indicators that are classified as quite good, namely the skill in formulating variables and the skill in presenting tables.

\section{Observation of Control Group Science Process Skills in Groups}

The group investigation model is essentially a model designed to guide and train students in defining problems, exploring problems, collecting data, developing and testing hypotheses (Trikasari, 2016). In applying this model students are actively involved in planning both the topic and the course of the investigation. Average of students' science process skills in groups in experiments I and II the experimental group can be seen in Figure 2.

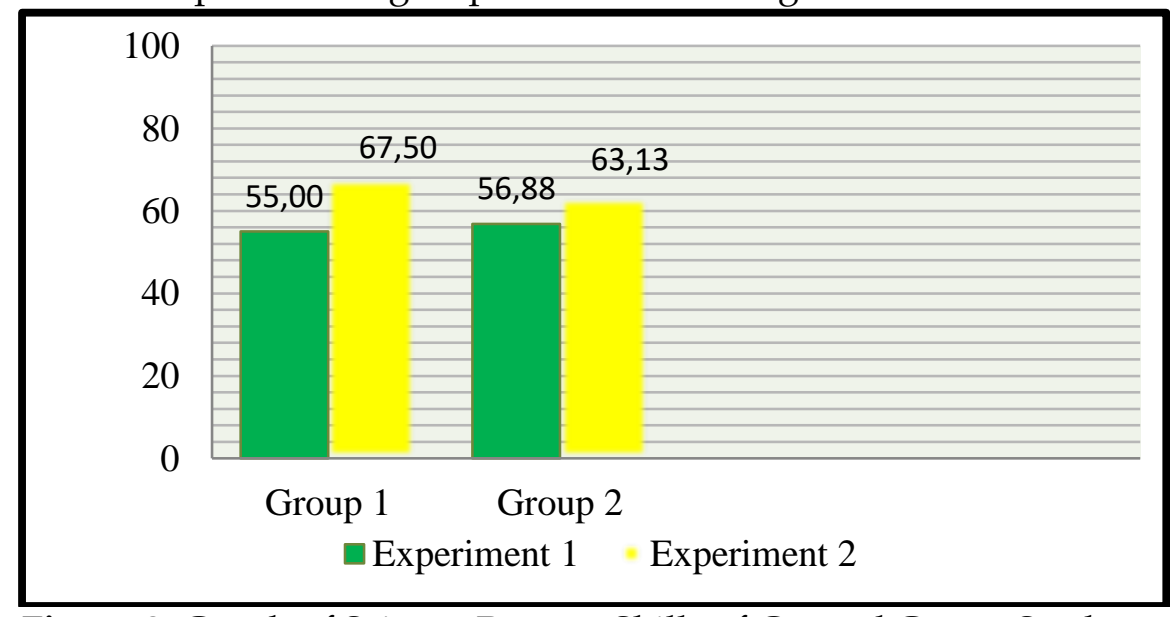

Figure 2. Graph of Science Process Skills of Control Group Students

Figure 2 above shows that the group data in the first experiment which obtained the lowest score was group I with a value of 55 and the group with the highest score was group II with a value of 56.88. In experiment II, the group that got the lowest score was group II with a score of 63.13 and the group with the highest score was group I with a score of 67.50 . Shows that the science process skills of all groups in the control group have increased in experiment II compared to experiment I. However, the increase is not relatively far, so many aspects of science skills are categorized as incomplete according to the KKM. This is because students are still confused about what they should do in the experiment because students do not have a structured guide when conducting the experiment.

\section{Control Group Science Process Skills in terms of Indicators}

Science process skills in terms of indicators were obtained by calculating the average score for each indicator of science process skills in both experiment I and experiment II. The average science process skills of students in each indicator on experimental I and II can be seen in table 9.

Table 9. The Value of the Control Group KPS Indicators in Experiments I and II

\begin{tabular}{lllllll}
\hline & \multicolumn{2}{l}{ Science process skills score } & & & \\
Aspect & Group 1 & category & Group 2 & category & average & category \\
\hline Formulate the problem & 60 & Enough & 67.5 & Good & 63.75 & Good \\
Formulate a hypothesis & 55 & Enough & 60 & Good & 57.5 & Good \\
Formulate variables & 50 & Enough & 67.5 & Good & 58.75 & Enough \\
Planning an experiment & 57.5 & Enough & 65 & Good & 61.25 & Good \\
Do an experiment & 57.5 & Enough & 67.5 & Good & 62.5 & Good \\
Drawing graphs/tables & 50 & Enough & 65 & Good & 57.5 & Enough \\
Interpretation & 60 & Enough & 67.5 & Good & 63.75 & Good \\
Communicate & 57.5 & Enough & 62.5 & Good & 60 & Enough \\
average score & & & & & 60,625 & Enough \\
\hline
\end{tabular}


Table 9 above shows that the average science process skills of all indicators in experiment I are categorized as good enough and have increased in experiment II, it's just that on average all indicators of science process skills are categorized as good enough and have not been completed in KKM in experiment I. The skill indicator in experiment II seems to have increased and is classified as good category with $75 \%$ of all science process skills complete.

\section{Hypothesis Testing of Students' Science Process Skills}

Based on the results of the prerequisite test, the analysis of the results of the pretest and posttest of students' science process skills, it was concluded that the experimental group and the control group had data that were normally distributed and the variance was homogeneous. Testing the research hypothesis to determine the effect of LKPD in facilitating group investigation to improve Students' Science Process Skills by using a free sample t-test in the SPSS version 20.00 program. Based on the results of the homogeneity test and posttest normality of the experimental-control group, it showed that both groups had homogeneous and normal variances, so that the requirements for using the free sample t-test in testing the hypothesis were fulfilled. Hypothesis decision making is if tcount $<$ ttable then Ho is accepted and Ha is rejected, whereas if tcount $\geq$ ttable then Ha is accepted and Ho is rejected.

Table 10. Hypothesis Test Results of Students' Science Process Skills

\begin{tabular}{lllllll}
\hline & & \multicolumn{2}{l}{$\begin{array}{l}\text { Levene's } \\
\text { of Variances }\end{array}$} & for Equality & \multicolumn{2}{c}{ t-test for Equality of Means } \\
& & F & Sig. & T & Sig. (2-tailed) \\
\hline Score & Equal variances assumed & 1.817 & .194 & 5.071 & .000 \\
& Equal variances not assumed & & & 5.071 & .000 \\
\hline
\end{tabular}

Table 10 above shows that the $t_{\text {count }}$ value is 5.071 , when compared with the value $t_{\text {table }}$ with degrees of freedom $d k=9$ and a significance level of $5 \%$ is 2.262. Both $t_{\text {count }}$ and $t_{\text {table }}$ values meet the pattern -ttable < tcount $>$ ttable $(-2.262<5.071>2.262)$, so it can be concluded that Ho is rejected and $\mathrm{Ha}$ is accepted. These results indicate that there is a significant effect of using LKPD in facilitating group investigation to improve students' science process skills.

\section{Student Response Questionnaire Analysis}

The results of the analysis of filling out the student response questionnaire sheet on the motion material using the LKPD-based Group Investigation learning model can be seen in Table 11.

Table 11. Student Response Questionnaire Analysis

\begin{tabular}{cccc}
\hline \multirow{2}{*}{ No } & \multirow{2}{*}{ Questionnaire indicators } & \multicolumn{2}{c}{ Evaluation } \\
\cline { 3 - 4 } & & Percentage & Category \\
\hline 1 & Suitability & $96 \%$ & Very good \\
\hline 2 & Help & $87.5 \%$ & Very good \\
\hline 3 & Convenience & $96.25 \%$ & Very good \\
\hline 4 & attractiveness & $96.25 \%$ & Very good \\
\hline & Total & $94 \%$ & Very good \\
\hline
\end{tabular}

Table 11 above shows the average percentage of total student responses in the use of the LKPD-based Group Investigation learning model is $94 \%$ with a very good response category. The data shows how happy students are in learning. The atmosphere of active and fun learning activities cannot be separated from the characteristics of the LKPD-based group investigation model. This is in line with the opinion expressed by Wahyuni et al. (2018), which states that the group investigation model will make students actively explore, build, and develop concepts, provide opportunities for students to develop science process skills, students get more attention when compared to lecture system, as well as enabling students to understand and fully understand the concepts taught by the teacher, because they were directly involved in the 
experiment. In addition, visually the results of the student response questionnaire applying the LKPD-based Group investigation learning model can also be seen in Figure 3.

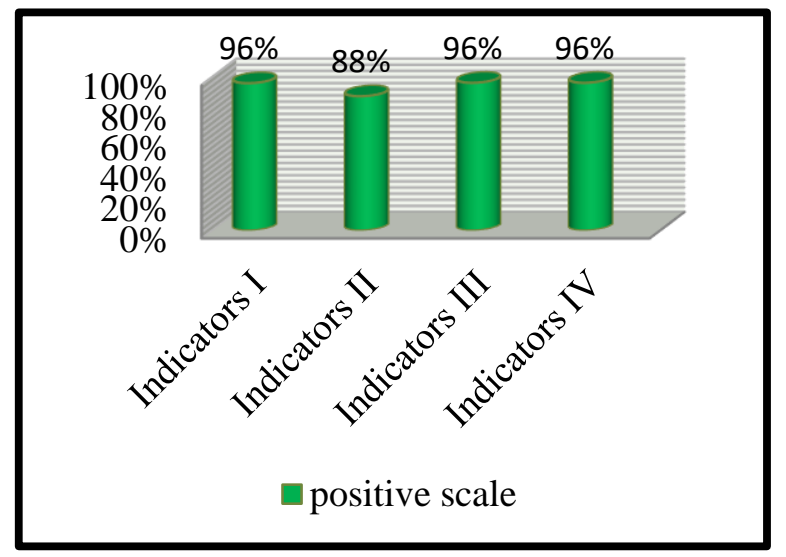

Figure 3. Student Response Questionnaire Diagram

\section{Teacher Learning Implementation}

The opinion of BSNP in Sulistiyono (2014) which states that the implementation of learning is the actualization of the Learning Implementation Plan (RPP). The results of the analysis of filling out the observation sheet on the implementation of teacher learning in the experimental class using the LKPD-based Group Investigation learning model can be seen in Table 4.18.

Table 12. Learning Implementation Analysis

\begin{tabular}{cccccc}
\hline \multirow{2}{*}{ No } & $\begin{array}{c}\text { The Implementation of } \\
\text { learning }\end{array}$ & Observer $\mathbf{1}$ & Observer 2 & $\begin{array}{c}\text { Average } \\
\text { percentage }\end{array}$ & Category \\
\hline 1 & meeting 1 & $89 \%$ & $94 \%$ & 0.915 & very good \\
\hline 2 & meeting 2 & $89 \%$ & $89 \%$ & 0.89 & very good \\
\hline \multicolumn{3}{c}{ Average score } & & 0.9025 \\
& \multicolumn{3}{c}{ Category } \\
\cline { 2 - 5 }
\end{tabular}

Table 12 above shows the average value of the total percentage of teacher learning implementation of object motion material using the LKPD-based Group Investigation learning model in the experimental group of $90 \%$ with the category of very good learning implementation. This shows that the teacher has carried out learning very well with the learning steps that have been fulfilled. In addition, visually the results of the analysis of the implementation of teacher learning in the subject of motion of objects using the LKPD-based Group Investigation learning model can be seen in Figure 4.

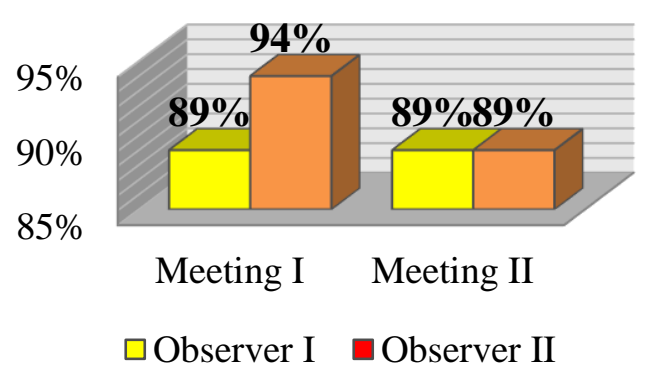

Figure 4. Teacher Learning Implementation Diagram

\section{CONCLUSION}

Research conducted in class VIII of MTs Al Miftah Modung for the 2020/2021 academic year on science learning material motion objects using LKPD to facilitate cooperative group investigation in improving students' science process skills it was concluded that there was an 
influence of LKPD to facilitate group investigation in improving science process skills student. With the average achievement of indicators of science process skills in the experimental group of 81.09 in the very good category, while the average indicator of science process skills in the control group is 60.625 in the enough good category. With the percentage of student response questionnaires of $94 \%$ in the very good category and the percentage of learning implementation of 90.25 in the very good category.

\section{REFERENCES}

Aiken, L, R. (1980). Content validity and reliability of single items or questionnaires. Educational and Psychological Measurement, 40, 955-967.

Arifin, Z. (2013). Evaluasi pembelajaran: Prinsip, teknik, prosedur. Remaja Rosdakarya.

Arikunto, S. (2015). Dasar-Dasar Evaluasi Pendidikan. Rineka Cipta.

Carin, A. A., \& Sund, R. B. (1989). Teaching modern science (3rd ed.). Charles E. Merrill Publishing.

Gasila, Y., Fadillah, S., \& Wahyudi, W. (2019). Analisis Keterampilan Proses Sains Siswa Dalam Menyelesaikan Soal IPA di SMP Negeri Kota Pontianak. Jurnal Inovasi dan Pembelajaran Fisika, 6(1), 14-22.

Gronlund, N. E. (1982). Constructing achievement tests (3rd ed.). Prentice Hall.

Hardani. (2020). Metode Penelitian. Pustaka Ilmu.

Prasetyaningsih, P., \& Wilujeng, I. (2016). Analisis kualitas pengelolaan kelas pembelajaran sains pada SMP Ssn di Kabupaten Pati. Jurnal Penelitian dan Pembelajaran IPA, 2(2), 147-165.

Purwanto. 2010. Evaluasi hasil belajar. Pustaka Pelajar

Salmina, M., \& Adyansyah, F. (2017). Analisis kualitas soal ujian matematika semester genap kelas XI SMA Inshafuddin Kota Banda Aceh. Numeracy, 4(1), 37-47.

Sanjaya, W. (2008). Strategi pembelajaran berorientasi standar proses pendidikan. Kencana Prenada Media Group.

Sayekti, I. C., \& Kinasih, A. M. (2017). Kemampuan guru menerapkan keterampilan proses sains dalam pembelajaran IPA pada siswa Sekolah Dasar. Profesi Pendidikan Dasar, 4(1), 97105.

Sharan, S. (1980). Cooperative learning in small groups: Recent methods and effects on achievement, attitudes, and ethnic relations. Review of Educational Research, 50(2), 241-271. https://doi.org/10.3102/00346543050002241

Slavin, R. E. (2010). Cooperatif learning: Teori, riset, dan praktik. Nusa Media.

Suastra, I. W. (2009). Pembelajaran sains terkini: Mendekatkan siswa dengan lingkungan alamiah dan sosial budayanya. Penerbit Universitas Pendidikan Ganesha.

Sugiyono. (2015). Statistika untuk Penelitian. Alfabeta.

Sulistiyono, S. (2021). Efektivitas model pembelajaran inkuiri terbimbing terhadap keterampilan proses sains dan pemahaman konsep fisika siswa MA Riyadhus Solihin. Jurnal Pendidikan Fisika Undiksha, 10(2), 61-73.

Trikasari, K. M., Ege, B., \& Supiandi, M. I. (2016). Penerapan model pembelajaran group investigation terhadap kemampuan pemecahan masalah siswa pada materi sistem pencernaan pada manusia. Jurnal Pendidikan Biologi, 1(1), 29-39.

Utami, S. D., Efendi, I., Dewi, I. N., Ramdani, A., \& Rohyani, I. S. (2019). Validitas perangkat pembelajaran etnoekologi masyarakat Suku Sasak kawasan taman nasional Gunung Rinjani. Jurnal Penelitian Pendidikan IPA, 5(2), 240-247.

Viyayanti, \& Dwikoranto. (2021). Make a match techniques in cooperative learning: innovations to improve student learning outcomes, student learning activities, and teacher performance. Studies in Learning and teaching, 2(2), 35-46. https://doi.org/10.46627/silet.v2i2.74

Wahyuni, N. L., Wibawa, I. M., \& Renda, N. T. (2018). Pengaruh model pembelajaran kooperatif tipe group investigation berbantuan asesmen kinerja terhadap keterampilan proses sains. International Journal of Elementary Education, 2(3), 202-210. 
Influence of LKPD to Facilitate Cooperative Group Investigation in Improving Students' Science Process Skills https:// doi.org/10.46627/silet.v2i3.85

Zubaidah, S. (2016). Keterampilan abad ke-21: Keterampilan yang diajarkan melalui pembelajaran. Seminar Nasional Pendidikan, 2(2), 1-17.

Author (s):

* Suliwa (Corresponding Author)

Graduate student of science education at Surabaya State University

Universitas Negeri Surabaya,

Jl. Lidah Wetan, Surabaya 60213, Indonesia

Email: suliwa.18051@mhs.unesa.ac.id

\section{Wahono Widodo}

Department of Physics Education, Faculty of Mathematics and Natural Science,

Universitas Negeri Surabaya,

Jl. Ketintang, Surabaya 60231, Indonesia

Email: wahonowidodo@unesa.ac.id

\section{Munasir}

Department of Physics, Faculty of Mathematics and Natural Science,

Universitas Negeri Surabaya,

Jl. Ketintang, Surabaya 60231, Indonesia

Email: munasir_physics@unesa.ac.id 